\title{
Peran Tayangan Adit Sopo Jarwo (ASJ) Terhadap Pendidikan Karakter Anak Sekolah Dasar di SDN 023 Sempaja Samarinda
}

\author{
Ratna Khairunnisa \\ Universitas Widya Gama Mahakam \\ ratna@uwgm.ac.id
}

\begin{abstract}
Abstrak
Pengabdian ini bertujuan untuk memberikan penguatan pendidikan karakter pada anak SD melalui tayangan film animasi "Adit Sopo Jarwo". Beberapa materi yang diberikan terkait dengan upaya penguatan pendidikan karakter anak SD khususnya pada SDN 023 Samarinda. Pentingnya tayangan yang layak ditonton oleh anak SD sehingga dapat menjadi pendamping pembelajaran yang positif dan menyenangkan. Dalam kegiatan penguatan pendidikan karakter melalui tayangan animasi ini yang menjadi peserta adalah siswa SDN 023 Samarinda. Metode yang diterapkan dalam kegiatan ini adalah sosialisasi. Dalam kegiatan sosialisasi terdiri dari beberapa kegiatan yang meliputi penyajian materi, diskusi dengan siswa dan refleksi. Penyajian materi yakni dengan menayangkan animasi Adit Sopo Jarwo dan menjelaskan pendidikan karakter yang terkandung di dalam tayangan tersebut Adapun metode Pengambilan Data yang dilakukan dalam pengabdian yakni dengan memberikan angket dan wawancara langsung dengan siswa seputar film adit sopo jarwo. Setelah mengikuti sosialisasi ini siswa dapat : (1) mengetahui pendidikan karakter yang ada dalam film animasi Adit Sopo Jarwo (2) mengetahui tayangan mana yang layak dan tidak layak untuk ditonton.
\end{abstract}

Kata kunci: Film Animasi Adit Sopo Jarwo, Pendidikan karakter 


\section{Jurnal Abdimas Mahakam \\ https://journal.uwgm.ac.id/index.php/abdimasmahakam \\ Online ISSN : 2549-5755 \\ Januari 2017, Vol.1 No. 1}

\section{Pendahuluan}

Pada zaman sekarang ini, Televisi merupakan media massa elektronik yang mampu menyebarkan berita secara cepat dan memiliki kemampuan mengakses informasi dan mencapai khalayak dalam jumlah tak terhingga pada waktu yang bersamaan. Salah satu media massa yang paling banyak memberikan infomasi adalah Televisi. Televisi dengan berbagai acara yang ditayangkannya telah mampu menarik minat pemirsanya, dan membuat pemirsanya 'ketagihan' untuk selalu menyaksikan acara-acara yang ditayangkan. Bahkan bagi anak-anak sekalipun sudah merupakan bagian yang tidak terpisahkan dari aktiviatas kesehariannya. Anak-anak bisa menghabiskan waktunya berjam-jam hanya untuk menonton televisi kesayangannya. Acara "nonton tv" sudah menjadi agenda wajib bagi mereka.

Dengan berbagai acara yang ditayangkan mulai dari infotainment, entertainment, iklan, sampai pada sinetron-sinetrom dan film-film yang berbau kekerasan, televisi mampu membius pemirsanya (anak-anak, remaja dan orang tua) untuk terus menyaksikan acara demi acara yang dikemas sedemikian mungkin dan dibubuhi dengan assesoris-assesoris yang menarik, sehingga membuat pemirsanya terkagum-kagum dengan acara yang disajikan. Tidak jarang sekarang ini banyak anak-anak lebih suka berlama-lama di depan televisi dari pada belajar, bahkan hampir-hampir lupa akan waktu makannya. Hal ini merupakan problematika yang terjadi dilingkungan kita sekarang ini dan perlu perhatian khusus bagi setiap orang tua untuk selalu mengawasi aktivitas anaknya. Tidak dipungkiri, dengan adanya media massa televisi ini banyak sekali manfaat yang bisa kita ambil. Dimana kita akan dengan cepat memperoleh informasi-informasi terbaru yang terjadi dimana pun dan belahan dunia manapun. Sehingga kita memperoleh wawasan yang luas dan tidak akan ketinggalan berita-berita terhangat masa kini, kita bisa mengetahui apa saja masalah-masalah yang sedang terjadi. Sebagai manusia global harus mampu mengkritisi dari berbagai aspek manapun baik sosial, ekonomi, politik, hukum, dan budaya. 


\section{Jurnal Abdimas Mahakam \\ https://journal.uwgm.ac.id/index.php/abdimasmahakam \\ Online ISSN : 2549-5755 \\ Januari 2017, Vol.1 No. 1}

Jika kita kaji lebih jauh, sebenarnya media massa televisi mempunyai fungsi utama yang harus diperhatikan yaitu fungsi informatif, edukatif, rekreatif dan sebagai sarana mensosialisasikan nilai-nilai atau pemahaman-pemahaman. Namun jika dlihat kenyataannya sekarang ini, acara-acara televisi lebih kepada fungsi informatif dan rekreatif saja. Sedangkan fungsi edukatif merupakan fungsi yang sangat penting untuk disampaikan atau diinformasikan sedikit sekali. Hal ini bisa kita lihat dari susunan acaraacara televisi, kebanyakan hanya acara-acara sinetron yang marak terdapat diberbagai channel televisi. Selain itu acara-acara infotainment yang membuat penontonnya terobsesi dengan gosip-gosip para artis. Sedangkan acara-acara yang mengarah kepada edukatif atau pendidikan kecil sekali frekuensinya.

Sebagai media audio visual, TV mampu merebut beberapa saluran masuknya pesan-pesan atau informasi ke dalam jiwa manusia yaitu lewat mata dan telinga. TV mampu membuat orang pada umumnya mengingat dari apa yang mereka lihat dan dengar dilayar televisi walaupun hanya sekali ditayangkan. Dengan demikian terutama bagi anak-anak pada umumnya selalu meniru apa yang mereka lihat, tidak menutup kemungkinan perilaku dan sikap anak tersebut akan mengikuti acara televisi yang ia tonton. Apabila yang ia tonton merupakan acara yang lebih kepada edukatif, maka akan bisa memberikan dampak positif tetapi jika yang ia tonton lebih kepada hal yang tidak memiliki arti bahkan yang mengandung unsur-unsur negatif atau penyimpangan bahkan sampai kepada kekerasan, maka hal ini akan memberikan dampak yang negatif pula terhadap perilaku anak yang menonton acara televisi tersebut.

Belakangan ini media massa menyajikan pandangan yang pro dan kontra terhadap draf Komisi Penyiaran Indonesia tentang Pedoman Perilaku Penyiaran dan Standar Program Siaran. Sebagian orang merasa apa yang diperdebatkan itu tak berkaitan langsung dengan kepentingan mereka, apalagi untuk anggota keluarga di rumah. Padahal, justru merekalah menjadi konsumen utama siaran televisi. Apa ditampilkan pesawat di ruang keluarga 


\section{Jurnal Abdimas Mahakam \\ https://journal.uwgm.ac.id/index.php/abdimasmahakam \\ Online ISSN : 2549-5755 \\ Januari 2017, Vol.1 No. 1}

sehari-hari bakal mewarnai kehidupan keluarganya kini, bahkan sampai masa mendatang. Sayangnya, selama ini bisa dikatakan tak banyak orangtua yang memberi perhatian pada pengaruh televisi terhadap tingkah laku atau kebiasaan anak-anaknya. Hal ini bisa dilihat dari sedikitnya respons pemirsa yang muncul terhadap program-program yang ditayangkan di layar kaca. Pemirsa di Indonesia tampaknya lebih suka menelan apa saja acara yang muncul pada pesawat televisinya. Mereka lebih memilih diam, dan tinggal memencet remote control bila acara yang ditampilkan satu stasiun televisi tidak sesuai dengan seleranya. Sebagian orangtua bahkan tak peduli acara apa yang ditonton anaknya. Sepanjang si anak tidak bertanya atau bercerita, umumnya orangtua merasa apa pun yang disuguhkan televisi sebagai "teman" anaknya selama mereka tidak berada di rumah tak perlu dipermasalahkan.

Jika ada pengaruh buruk televisi terhadap sebagian orang, maka sebagian lainnya menganggap hal itu sama sekali bukan urusannya. Padahal, sangat mungkin pengaruh buruk itu pun mengenai anggota keluarganya, hanya dia tak cukup jeli atau punya cukup waktu untuk memperhatikannya. Meski ada keluhan yang mengemuka, toh sinetron itu tetap ditayangkan seperti biasa. Bagi umumnya pengelola stasiun televisi, sepanjang program tersebut bisa mengundang pengiklan berarti tak ada masalah. Hal ini juga berlaku, misalnya, pada protes sebagian orangtua ketika stasiun televisi menayangkan acara anak-anak pada pagi hari. Acara itu menyerap perhatian si anak hingga mengganggu persiapan mereka pergi ke sekolah. Namun, ibarat pepatah anjing menggonggong kafilah berlalu, maka program itu pun tetap berjalan. Silakan para orangtua sibuk membujuk anaknya agar mengalihkan perhatiannya dari layar kaca. Memang tak semua pengaruh televisi bisa langsung tampak akibatnya pada anak-anak yang menjadi pemirsanya. Mungkin karena itulah sampai sekarang masih banyak orangtua yang membiarkan apa pun acara yang ingin ditonton anaknya. sepanjang itu tak lebih dari pukul 21.00. Sebagian orangtua beranggapan, stasiun televisi telah menyeleksi program acaranya. Dengan demikian, semua acara yang ditayangkan sebelum sekitar pukul 21.00 relatif aman untuk konsumsi anak-anak. Padahal kalau dicermati, tak sedikit acara sebelum pukul 21.00 yang sebenarnya tak pantas ditonton anak-anak. Misalnya, 


\section{Jurnal Abdimas Mahakam \\ https://journal.uwgm.ac.id/index.php/abdimasmahakam \\ Online ISSN : 2549-5755 \\ Januari 2017, Vol.1 No. 1}

film-film Warkop yang jelas-jelas selalu menyerempet pada hal-hal berbau seks.

Kurangnya tayang-tayangan yang cocok untuk ditonton oleh anak menjadi salah satu faktor anak-anak dirumah menonton tayangan yang bukan diperuntukkan mereka. Salah satu tayangan yang menurut peneliti cocok untuk ditonton oleh anak-anak adalah serial Adit dan Sopo Jarwo. Tayangan tersebut banyak merefleksikan apa yang dilakukan oleh anak-anak pada umumnya dan diselingi dengan nasihat-nasihat oleh karakter ustadz pada tayangan tersebut. Oleh karena itu kami tertarik untuk melakukan pengabdian msyarakat tentang penguatan karakter anak memlaui tayangan animasi film Adit Sopo Jarwo di SDN 023 Samarinda.

\section{Tujuan}

Berdasarkan permasalahan yang dikemukakan di atas, makalah ini disusun dengan tujuan untuk:

1. Mengetahui peranan film Adit Sopo Jarwo bagi penguatan karakter anak di SD 23 Samarinda?

2. Mengetahui hikmah film adit sopo jarwo bagi kehidupan keseharian anak ?

3. Mengetahui tayangan yang layak ditonton oleh anak SD sehingga dapat menjadi pendamping pembelajaran yang positif dan menyenangkan?

\section{Manfaat Kegiatan Pengabdian Kepada Masyarakat}

Setelah memperoleh kegiatan sosialisasi ini, para siswa dapat mengetahui hikmah yang ada dalam film adit sopo jarwo dan memberikan gambaran tentang usaha-usaha yang harus dilakukan dalam mengatasi dampak negatif tayangan televisi.

\section{Metode}

Adapun langkah yang akan ditempuh dalam kegiatan PPM kali ini mencakup beberapa tahap berikut ini.

1) Persiapan

Tahap persiapan merupakan tahap awal sebelum pelaksanaan PPM. Dalam tahap ini ada beberapa hal yang dilakukan:

a. Koordinasi Internal, dilakukan oleh Tim untuk merencanakan pelaksanaan 


\section{Jurnal Abdimas Mahakam \\ https://journal.uwgm.ac.id/index.php/abdimasmahakam \\ Online ISSN : 2549-5755 \\ Januari 2017, Vol.1 No. 1}

secara konseptual, operasional, serta job-description masing-masing anggota,

b. Penentuan dan rekruitment peserta sosialisasi,

c. Pembuatan Instrumen PPM, seperti lembar presensi, angket, lembar kerja

d. Pembuatan modul pelatihan Powerpoint, dan

e. Persiapan konsumsi, publikasi, lokasi, dokumentasi, dsb.

\section{2) Pelaksanaan Pelatihan}

Tahap ini merupakan tahap pelatihan yang diberikan kepada siswa SDN 023 Samarinda. Pelaksanaan sosialisi ini mencakup beberapa hal berikut.

\section{a. Penyajian Materi}

Materi yang disajikan terkait dengan tentang pendidikan karakter, menayangkan animasi Adit Sopo Jarwo dan menjelaskan pendidikan karakter yang terkandung di dalam tayangan tersebut. Penyaji materi adalah tim pengabdi sendiri disesuaikan dengan bidang keahlian masing-masing.

\section{b. Diskusi}

Pada akhir materi peserta akan diberi kesempatan untuk berdiskusi tentang materi yang sudah disampaikan.

\section{c. Refleksi dan Penutupan Program PPM}

Di akhir kegiatan peserta dan Tim melakukan refleksi hasil sosialisasi dan para peserta juga memberikan evaluasi terhadap apa yang sudah ditonton ini.

Setelah semua kegiatan yang telah direncanakan terlaksana, ketua tim PPM menutup program dan memberikan pesan kepada segenap peserta sosialisasi untuk menerapkan karakter positif yang ada dalam hikmah film adit sopo jarwo dan memberikan pesan apa yang untuk siswa lebih selektif dalam memilih dan dapat mengetahui tayangan mana yang layak dan tidak layak untuk ditonton. Diharapkan pada PPM yang akan akan datang program ini dapat dilanjutkan lagi dan dapat lebih menjangkau jumlah sekolah lain tak hanya satu sekolah dasar saja, sehingga kebermanfaatan program ini dapat dirasakan oleh sekolah yang lebih banyak. 


\section{Jurnal Abdimas Mahakam \\ https://journal.uwgm.ac.id/index.php/abdimasmahakam \\ Online ISSN : 2549-5755 \\ Januari 2017, Vol.1 No. 1}

\section{Pengambilan Data}

Dalam kegiatan penguatan pendidikan karakter melalui tayangan animasi ini yang menjadi peserta adalah siswa sekolah dasar SDN 023 Teknik atau Metode Pengambilan Data yang dilakukan pengabdi adalah dengan memberikan angket dan wawancara dengan melakukan tanya jawab tentang hasil yang dari kegiatan sosialisasi tersebut.

\section{Hasil dan Pembahasan}

\section{A. Hasil Pelaksanaan Kegiatan Pengabdian Masyarakat}

Pertama masuk ke kelas, kami menyapa siswa dan menanyakan tentang film adit sopo jarwo. Siswa terlihat sangat antusias. Film yang yang ditampilkan yakni dua film dengan tema yang berbeda dan masing-masing berdurasi sekitar 8 sampai 10 menit. Dalam setiap film yang diputar langsung dilanjutkan dengan kegiatan sosialisasi hikmah yang terkandung didalammnya.

Film pertama yang diputar tentang kegiatan berkemah. Hikmah yang diajarkan dalam film pertama ini tentang keberanian, pantang menyerah, semangat, optimis, mandiri, tanggung jawab dan peduli dengan sesama.

Siswa diajak berdiskusi langsung seputar karakter film yang ada. Siswa menyampaikan cerita kesehariannya sebagaimana yang ada dalam karakter film adit sopo jarwo. Salah satu siswa hendra maju ke depan dan menceritakan tentang nilai semangat. Dia mengatakan semangat itu bermanfaat untuk kita smua. Semangat itu tidak mudah menyerah, menurut hendra orang yang semangat akan sukses sekolahnya. Bahkan ada satu siswa yang mengaitkan semangat dan pantang menyerah ini dalam kegiatan dan aktivitasnya saat akan mengerjakan tugas di sekolah.

Film kedua yang ditayangkan tentang "lomba memancing”. Dalam film ini tergambar karakter tokoh yang meminta maaf dan yang lain memaafkan. Keberanian dalam minta maaf yang tergambar dalam tokoh ini bisa menjadi teladan bagi siswa untuk selalu menerapkan sikap tidak malu meminta maaf dan memberi maaf.

Setelah menonton film kedua ini. Kami mencoba menanyakan kepada siswa di kelas yang 


\section{Jurnal Abdimas Mahakam \\ https://journal.uwgm.ac.id/index.php/abdimasmahakam \\ Online ISSN : 2549-5755 \\ Januari 2017, Vol.1 No. 1}

sedang memiliki masalah. Kemudia reza mengacungkan tangannya dan menyampaikan bahwa dia tadi pagi habis bertengkar dengan Levi. Karena Levi mengolok Reza dengan sebutan si kecil. Kemudian kami meminta kedua siswa maju dan membantu mendamaikan keduanya. Si Levi pun tanpa ragu meminta maaf kepada Reza dan Reza memberikan maaf kepada Levi. Suasa siswa sangat antusias. Kelas terlihat asyik dan menyenangkan. Levi dan Reza telah berdamai. Semua siswa bertepuk tangan bahagia.

Kami juga menyampaikan hikmah dalam kedua film ini dengan bahasa yang ringan dan mudah dipahami siswa SD. Kedua hikmah dalam film disampaikan dan dikaitkan dengan keseharian. Semua siswa berjanji bersama menanamkan setiap karakter positif yang ada dalam film Adit Sopo Jarwo.

Dalam kegiatan penutup, kami juga menjelaskan tentang kriteria dari film yang layak tonton dan tidak layak ditonton. Anak-anak menyebutkan berbagai film yang diketahuinya dan kami mencoba memberikan penguatan tentang tayangan yang layak untuk ditonton dan bermanfaat serta menyampaikan dampak negatif jika menonton film yang tidak layak ditonton.

\begin{tabular}{ccr}
\hline $\begin{array}{c}\text { Jenis } \\
\text { Kegiatan }\end{array}$ & Pokok Bahasan (Materi) & Pemateri \\
\hline Teori & ilan tentang film “Adit Sopo Jarwo" & Nur Agus Salim, M.Pd \\
Pratik & Menonton film pertama & Tim Pengabdian \\
& Tanya jawab seputar film yang sudah ditonton & Ratna Khairunnisa, M.Pd \\
& film yang ditonton & Gamar Al Haddar, M.Pd \\
& sikap dan nilai dalam film & $\begin{array}{r}\text { Ratna Khairunnisa, M.Pd } \\
\text { \& Nur Agus Salim, M.Pd }\end{array}$ \\
Praktik & on film kedua & Tim pengabdian \\
& awab seputar film yang sudah ditonton & Gamar Al Haddar, M.Pd
\end{tabular}

Film kedua

Ratna Khairunnisa, M.Pd 


\section{Jurnal Abdimas Mahakam \\ https://journal.uwgm.ac.id/index.php/abdimasmahakam \\ Online ISSN : 2549-5755 \\ Januari 2017, Vol.1 No. 1}

\begin{abstract}
sikap dan nilai dalam film
Refleksi

llan tentang film yang layak tonton dan tidak tonton
\end{abstract}

Wawancara

Wawancara

Wawancara
Kegiatan keseharian dan karakter yang ada.

jDN 023 Samarinda

DN 023 Samarinda

ua siswa SDN 023 Samarinda
Gamar Al Haddar, M.Pd \&

Ratna Khairunnisa, M.Pd

Nur Agus Salim, M.Pd

Tim Pengabdian

Gamar Al Haddar, M.Pd

Ratna Khairunisa, M.Pd

Nur Agus Salim, M.Pd

\section{Tabel 1 Daftar Jenis Kegiatan, Materi, Pemateri}

\section{B. Pembahasan}

Anak-anak sangat tertarik dengan media film animasi. Penyampaian pesan nilai-nilai positif untuk penguatan karakter menjadi lebih memiliki daya tarik tersendiri jika disampaikan lewat film. Film animasi adit sopo jarwo yang disajikan dengan bahasa yang mudah dipahami membuat ana-anak menjadi lebih menyenangkan.

Dalam kegiatan pengabdian ini siswa belajar langsung dari media animasi film "Adit Sopo Jarwo" dan ditambahkan penjelasan serta pengarahan dari kelompok pengabdian. Hikmah yang didapatkan siswa mengetahui dan mengerti tentang : keberanian, pantang menyerah, semangat, optimis, mandiri, tanggung jawab dan peduli dengan sesama. Selain itu siswa juga memahami tentang pentingnya meminta maaf dan memberi maaf sebagaimana yang diajarkan dalam film kedua. Siwa menjadi lebih peka dan tidak malu untuk meminta maaf jika melakukan kesalahan dan mau memberikan maaf kepada teman yang berbuat kesalahan.

Di zaman yang serba modern seperti sekarang, penguatan karakter memiliki nilai yang sangat penting. Semakin banyak anak memiliki karakter yang baik maka akan membuat lingkungan di sekitarnya menjadi lebih baik. Media bisa menjadi alat bantu untuk 


\section{Jurnal Abdimas Mahakam \\ https://journal.uwgm.ac.id/index.php/abdimasmahakam \\ Online ISSN : 2549-5755 \\ Januari 2017, Vol.1 No. 1}

membantu menguatkan karakter anak tetapi tetap diperlukan pendampingan dari guru dan orang tua untuk menekankan lagi tentang hikmah atau pesan yang disampaikan dalam film animasi.

\section{Hasil dan Pembahasan}

Berdasarkan kegiatan pengabdian kepada masyarakat ini dan uraian pembahasan di atas, dapat disimpulkan beberapa hal sebagai berikut:

1. Kegiatan ini memberikan beberapa materi yang terkait dengan upaya penguatan pendidikan karakter anak SD khususnya pada SDN 023Samarinda.

2. Nilai karakter yang ada dalam tanyangan film adit sopo jarwo yakni tentang keberanian, pantang menyerah, semangat, optimis, mandiri, tanggung jawab, peduli dengan sesama, meminta maaf dan memberikan maaf.

3. Memberikan arahan dalam memilih tayangan yang layak ditonton oleh anak sehingga dapat menjadi pendamping pembelajaran yang positif dan menyenangkan.

Sedangkan saran yang bias di usulkan adalah sebagai berikut:

1. Hendaknya kegiatan ini dilanjutkan untuk disosialisaikan di sekolah-sekolah yang lain agar anak-anak dapat lebih cermat dalam milih tanyangan film animasi yang positif dan bermanfaat

2. Diadakan sosialiasi lanjutan yang mengumpulkan guru dan orang tua untuk memberikan gambaran tentang tips mendampingi anak ketika menonton tanyangan film animasi. 


\section{Jurnal Abdimas Mahakam \\ https://journal.uwgm.ac.id/index.php/abdimasmahakam \\ Online ISSN : 2549-5755 \\ Januari 2017, Vol.1 No. 1}

\section{Daftar Pustaka}

Agus Wibowo. (2012). Pendidikan Karakter: Strategi Membangun Karakter Bangsa Berperadaban. Yogyakarta: Pustaka Pelajar

Buchory M. Sukemi. (2012). Implementasi Pendidikan Karakter di Indonesia dalam Seting Sekolah. Proceeding, Seminar Nasional. Yogyakarta: IKA UNY.

Darmiyati Zuchdi. (2011). Pendidikan Karakter dalam Perspektif Teori dan Praktik.rev.ed. Yogyakarta: UNY Press.

Darmiyati Zuchdi. (2011). Pendidikan Karakter dalam Prespektif Teori dan Praktik. Yogyakarta: UNY Press.

Dharma Kesuma, dkk. (2011) Pendidikan Karakter: Kajian Teori dan Praktik di Sekolah. Bandung: PT Remaja Rosdakarya.

Doni Kesuma A. (2009). Pendidikan Karakter di Zaman Keblinger. Jakarta: Grasindo.

Furqon Hidayatullah. (2010). Pendidikan Karakter: Membangun Peradaban Bangsa. Surakarta: Yuma Pustaka.

Jamal Ma'mur Asmani. (2012). Buku Panduan Internalisasi Pendidikan Karakter di Sekolah. Yogyakarta: Diva Press.

Lexy J. Moleang. (2007). Metode Penelitian Kualitatif. Bandung: PT Remaja Rosdakarya.

Masnur Muslich. (2011). Pendidikan Karakter: Menjawab Tantangan Krisis Multidimensional. Jakarta: Bumi Aksara.

Matthew B. Miles dan A. Michael Huberman.(1992). Analisis Data Kualitatif. Jakarta: UI Press.

Moh. Nazir. (2005). Metode Penelitian. Bogor: Ghalia Indonesia.

Muchlas Samani dan Hariyanto. (2012). Konsep dan Model Pendidikan Karakter. Bandung: PT Remaja Rosda Karya.

Punaji Setyosari. (2010). Metode Penelitian Pendidikan dan Pengembangan. Jakarta. Prenada Media Group. 


\section{Jurnal Abdimas Mahakam}

https://journal.uwgm.ac.id/index.php/abdimasmahakam

Online ISSN : 2549-5755

Januari 2017, Vol.1 No. 1

Sudarmadi. (2012). Implementasi Pendidikan Karakter Pembentukan Akhlak Mulia Pendidik dan Peserta Didik melalui Program Sekolah. Proceeding, Seminar Nasional. Yogyakarta: IKA UNY.

Sugiyono. (2010). Metode Penelitian Kuantitatif, Kualitatif, dan R\&D. Bandung: Alfabeta.

Suharsimi Arikunto. (2010). Prosedur Penelitian: Suatu Pendekatan Praktik. Jakarta: Rineka Cipta.

Sukandarrumidi. (2002). Metodologi Penelitian Petunjuk Praktis untuk Peneliti Pemula. Yoggyakarta: GM Univ.

Sukardi. (2007). Metodologi Penelitian Pendidikan: Kompetensi dan Praktiknya. Jakarta: Bumi Aksara.

Zubaedi. (2011). Desain Pendidikan Karakter. Jakarta: Kencana Prenada Media Group. 